\title{
Intellectual property protection in plant varieties: A worldwide index (1961-2011)
}

\author{
Mercedes Campi*, Alessandro Nuvolari \\ Institute of Economics, Scuola Superiore Sant'Anna di Studi Universitari e Perfezionamento, Piazza Martiri della Libertà 33, 56127 Pisa, Italy
}

\section{A R T I C L E I N F O}

\section{Article history:}

Received 3 April 2013

Received in revised form 3 November 2014

Accepted 5 November 2014

Available online 25 November 2014

\section{JEL classification:}

010

034

050

Q19

Keywords:

Intellectual property rights

Plant breeders' rights

UPOV Convention

International comparison

\begin{abstract}
A B S T R A C T
In this paper, we construct a new index measuring the strength of intellectual property (IP) protection for plant varieties in 69 countries over the period 1961-2011. We examine the statistical properties of the index and compare it with other indicators of IP protection. We conclude that the index provides a reasonable synthetic assessment of the relative strength of IP protection in plant varieties across countries. In addition, we study the main determinants of the evolution of the index and examine the patterns of correlation between the index and agricultural production.
\end{abstract}

(C) 2014 Elsevier B.V. All rights reserved.

\section{Introduction}

In 2005 and 2006, Monsanto began a systematic campaign of infringement suits against importers of Argentinian soybean products and by-products to Europe. In brief, the root of the controversy was that Monsanto's patent on the "Roundup Ready" (RR) soybean gene had been denied in Argentina but it had been granted by the European Patent Office (EPO). Therefore, Monsanto argued that imports from Argentina of soybean related products containing the RR gene were liable for infringement (Kranakis, 2007, pp. 723-724). Monsanto was successful in obtaining the impoundment of several shipments of soybean-related products in Spain, the UK and the Netherlands (Correa, 2009). Soybean and its by-products were and still are the major export staple of Argentina (representing more than $50 \%$ of agricultural exports). To date, both a UK court and the European Court of Justice have ruled against Monsanto (Cohen and Morgan, 2008).

In 2012, the United States and Colombia signed a trade agreement establishing that Colombian farmers could only use "certified seeds", effectively prohibiting the widespread practice of selfreproduction of seeds. This decision triggered a wave of major protests, strikes and demonstrations all over the country, which finally forced the government to suspend the infamous "seed law". ${ }^{1}$

These two episodes starkly illustrate the significance that intellectual property rights (IPRs) for plant varieties have attained in the world economy. In the last 30 years or so, plant breeding and the commercialization of seeds have witnessed dramatic growth at the global level. The International Seed Federation (www.worldseed.org) estimates an increase in the international seed trade from less than USD 1 billion in 1970 to more than USD 10 billion in 2010. The value of domestic seed markets has also presumably been growing at a similar pace. In addition, global agricultural R\&D spending has increased during the 2000-2008 period from $\$ 26.1$ billion to $\$ 31.7$ billion in 2005 constant prices (22\%) (Beintema et al., 2012).

As it is well known, the ratification of the agreement on Trade Related Aspects of Intellectual Property Rights (TRIPS) in 1994 has resulted in the adoption of tighter regimes of intellectual

\footnotetext{
* Corresponding author. Tel.: +39 050 883343; fax: +39 050883344.

E-mail addresses: m.campi@sssup.it (M. Campi), alessandro.nuvolari@sssup.it (A. Nuvolari).
}

\footnotetext{
1 http://www.gmwatch.org/index.php/news/archive/2013/15062-colombianfarmers-get-seeds-control-law-suspended (accessed 09.03.14).
} 
property rights in many developing countries. ${ }^{2}$ In particular, the TRIPS agreement demands higher protection in domains that, in many countries, were previously not covered by formal IPRs, such as genetic resources (including plant varieties). To date, most research on the effects of TRIPS and on the impact of IPRs regimes on the world economy has typically focused on patents and their effects on the performance of the manufacturing sector. Meanwhile, other types of IP protection that are particularly relevant for agriculture, such as plant breeders' rights (PBRs), have been relatively neglected.

This limited attention towards IPRs in agriculture by economists of innovation is unfortunate because the assessment of the merits and limitations of different IPRs regimes in this domain is particularly complex. A proper appraisal of this issue requires consideration of an intricate array of thorny policy issues, ranging from the suitability of patents versus sui generis forms of intellectual property (IP) protection as the most appropriate incentive system for stimulating innovations, to the moral and ethical aspects revolving around the consideration of living organisms as inventions (see Dutfield (2011) and Nuvolari and Tartari (2014) for historical overviews). Furthermore, recent developments in molecular biology applied to agriculture have contributed to increasing the complexity of this landscape. Genetically modified varieties may now be regarded as composed by different elements (the plant variety itself and its related gene), which can be protected by different types of IPRs and can even be owned by different actors. In this way, plant breeding has become an economic activity that is at the very core of the interests of major multinational companies involved in the production of genetically modified seeds. These developments have inevitably triggered conflicts, disputes and lobbying actions around IP protection for seeds.

The main objective of this paper is to contribute to this line of research by proposing a new index that provides an effective characterization of the relative strength of IP protection on plant varieties at the country level. Following the seminal contribution of Ginarte and Park (1997), similar indices have been constructed for assessing the strength of patent protection and, more generally, of the overall IPRs system at the country level. These indices have been a useful tool for unravelling broad patterns of correlation between IPRs regimes and indicators of innovation and economic performance such as R\&D investment, productivity and GDP. ${ }^{3}$

Because the effects of IPRs tend to be highly sector specific (Teece, 1986; Dosi et al., 2006), the construction of a new indicator explicitly focused on IP protection in agriculture can be a useful tool for researchers interested in assessing the effects of IPRs on innovation, growth, technology transfer, trade and productivity in this sector. ${ }^{4}$

The index was constructed by means of a detailed study of the evolution of the legislation in each country. Our approach has been thoroughly comparative from the outset: we have tried to identify the key-features characterizing the differences of IPRs systems for plant varieties at the country level and we have developed a simple approach for transforming these features in quantitative indicators. Subsequently, we have aggregated these indicators in a composite index. We have checked the robustness and plausibility of the index using different methods of aggregation of the

\footnotetext{
2 The TRIPS agreement was negotiated at the end of the Uruguay Round of the General Agreement on Tariffs and Trade (GATT) in 1994 and became effective in 1996.

${ }^{3}$ For example, among many others, see Kanwar and Evenson (2003) and Lederman and Saenz (2005).

${ }^{4}$ In a related contribution, Campi and Dueñas (2014) use the index to study the effect of IPRs on the trade of agricultural products.
}

individual components and examining its correlation with other measures of IP protection.

In this paper, we also provide an exploratory appraisal of the connection between our index and other variables and indicators by means of two econometric exercises. In the first one, we investigate the possible determinants of the strength of IP protection for plant varieties at the country level. In the second one, we examine the correlation between the index and agricultural production. In these two exercises, we shall explicitly take into account the different level of development of countries because we are particularly interested in unravelling whether the impact of IPRs displays different effects in developing and developed countries. This issue is especially relevant because the TRIPS agreement promotes the diffusion of harmonized IPRs systems to developing countries with little consideration of their specificities.

The rest of the paper is organized as follows. In the next section, we introduce the index and the sources used for its construction and discuss its main properties. Section 3 examines the trends of evolution of the index across countries. Section 4 contains our econometric investigation of the possible determinants of the index. Section 5 provides an appraisal of the patterns of correlation between the index and agricultural production at the country level. Section 6 concludes.

\section{Measuring IP protection for plant varieties}

Measuring the relative "strength" of IP protection has been a key issue in the literature addressing the impact of IPRs on innovation and economic performance at the country level. Accordingly, several contributions have been devoted to constructing synthetic indices of IP protection. ${ }^{5}$ Gadbaw and Richards (1988) have constructed a measure of IP protection for seven developing countries for the period 1984-1988. Rapp and Rozek (1990) have developed an index measuring the strength of patent systems in 159 countries for the year 1984. Sherwood (1996) has also developed a similar index for a cross-section of 18 developing countries. Lerner (2002) has examined shifts in the strength of patent protection across 60 countries over a 150-year period. Finally, the most used and wellknown index of patent protection is the one constructed by Ginarte and Park (1997) for 110 countries for the period 1960-1990 and, subsequently, updated until 2005 . $^{6}$

Some contributions have also been devoted to constructing sector-specific measures of IP protection. Liu and La Croix (2014) have developed an index that measures IP protection in the pharmaceutical sector. They found that their index starts at low levels in 1960, increases slowly through the early 1990s and dramatically grows thereafter due to the minimum standards set by the TRIPS agreement. Pugatch (2006) has also proposed another index of the strength of IP protection in the pharmaceutical industry for the US, UK, Singapore and Israel. Reynolds (2004) has proposed a similar measure of copyright protection and trademark rights. He found that copyright and trademark indices have been increasing by approximately 36\% between 1990 and 2000 .

\footnotetext{
${ }^{5}$ By and large, most of these indices are based on the appraisal of formal legislation rather than its actual enforcement. Of course, one may argue that the actual implementation and enforcement of a IPRs regime may be more relevant than its formal character. However, actual implementation is clearly much more difficult to characterize and measure. Conversely, legislators clearly do not intend for their regulations not to be enforced; rather, they expect the rules and laws that they enact to be implemented and binding. For these reasons, one should expect some kind of connection between the formal legislation and actual implementation of IP protection laws. On this issue, see Ginarte and Park (1997, pp. 289-291).

${ }^{6}$ Revisions and updates of the index of Ginarte and Park (1997) can be found in Park (2001); Park and Wagh (2002); and Park (2008).
} 


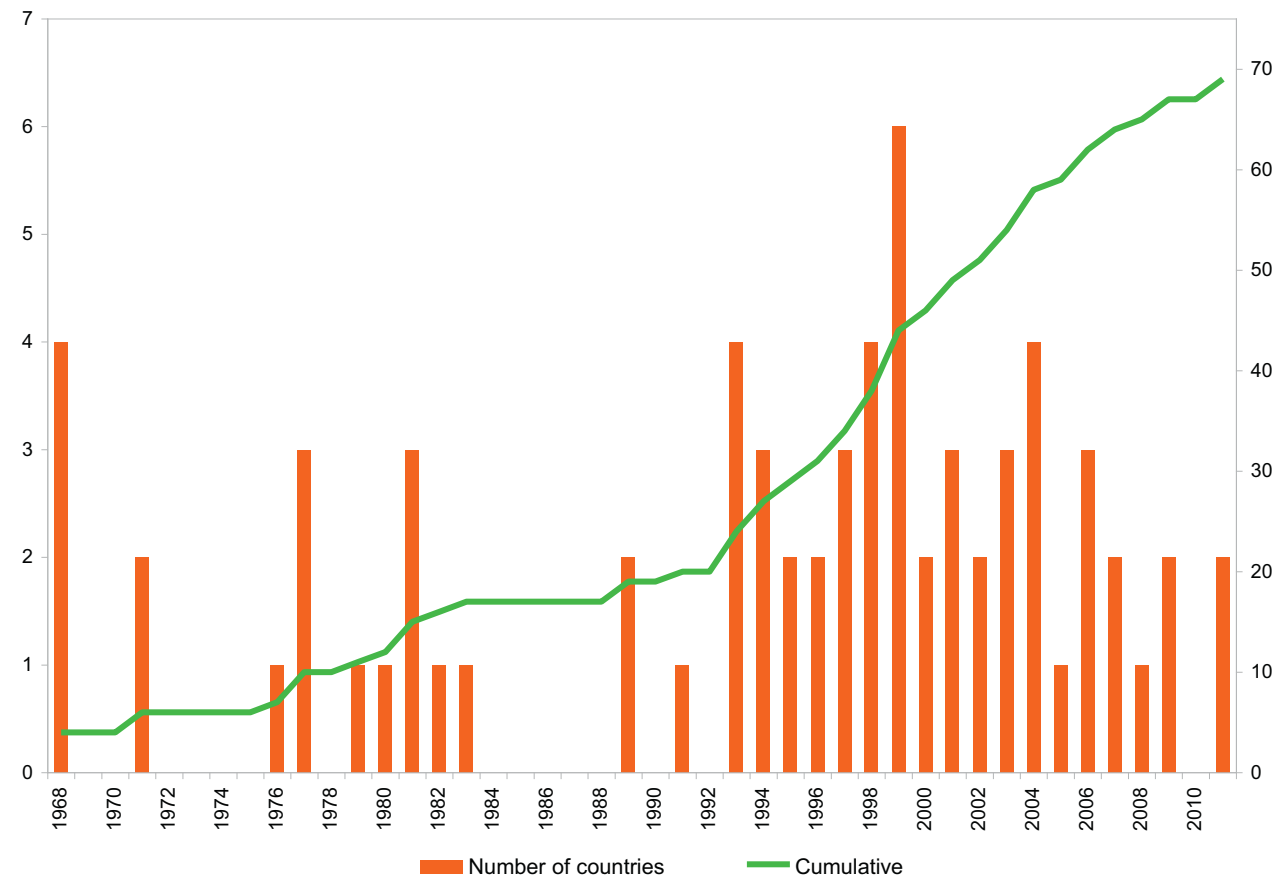

Fig. 1. Number of countries becoming members of UPOV by Year.

Current IP protection systems for plant varieties are the outcome of a complex historical process that has taken place at different pace across the world. Broadly speaking, there are two main forms of IP protection for plant varieties: patents and plant breeders' rights. Both of them grant a temporally limited exclusive control over the propagating material and the harvested material of a new plant variety. However, a PBR is a form of IP protection especially designed to protect plant varieties and, as such, it considers explicitly some of their specific attributes. In particular, plant varieties are characterized by a relatively high cost of development but a low cost of reproduction. Innovation in plant varieties is cumulative and access to "protected" material is needed to attain further improvements. Furthermore, some plant varieties are characterized by "self-reproduction" in the sense that the access to the plant material is enough for permitting its easy replication. Finally, in several cases, it is not obvious which plant varieties can be genuinely regarded as inventions.

To be a suitable matter for a PBR, a plant variety must be new, distinct (i.e., the plant variety in question should be different from those whose existence is a matter of common knowledge at the time the application is filed), sufficiently uniform and stable (i.e., the plant variety characteristics should be genetically fixed and remain unchanged from generation to generation). ${ }^{7}$ PBRs typically prescribe some exceptions or limitations to the rights of the holders that are not contemplated for patents: (i) breeders' exception, which allows breeders to use protected plant varieties for conducting research leading to a new variety; and (ii) farmers' exception, which allows farmers (buyers) to self-reproduce seeds from plant varieties they have purchased in order to use them in their own farms.

For long time, in most countries, new plant varieties were not regarded as a patentable subject matter. The United States Plant Patent Act of 1930, introducing patentability of asexually reproduced plants, is frequently considered a major historical turning

\footnotetext{
7 In the case of patents, an invention must meet the following requirements: novelty, non-obviousness (involving a significant inventive step), and usefulness or susceptibility of industrial application.
}

point in the evolution of plant breeding legislation (Moser and Rhode, 2011). Most countries refused to follow the American example preferring instead to work at the development of new "ad hoc" forms of protection. In 1961, the International Convention for the Protection of New Varieties of Plants (UPOV) was drafted to promote an international and relatively harmonized system of IP protection especially designed for plant varieties with common basic guidelines for its members. Since then, most countries have adopted sui generis systems such as PBRs for the protection of plant varieties. More recently, UPOV has also accepted "double protection", allowing both patents and PBRs. While some countries (United States, South Korea, Japan and Australia) endorse double protection, the European Patent Convention (EPC) excludes plant varieties and essentially biological processes for the production of plants from patent protection (Janis, 2014).

In a long-term perspective, one can point to examples of countries that have been very keen in offering IPRs for plant varieties, as well as countries that have been extremely reluctant to introduce them. Recently, the TRIPS agreement has determined a generalized progressive diffusion and tightening of IPR systems for plant varieties. Article 27.3(b) establishes that members of the World Trade Organization (WTO) may exclude from patentability plants and animals other than microorganisms, but they must provide protection for plant varieties, by means of patents, an effective sui generis system or by any combination thereof. As shown in Fig. 1, until the early 1990s, the UPOV Convention was subscribed to by a relatively small group of countries, but since then, its membership has expanded considerably.

Fig. 2 shows this historical development from a geographical point of view. Before the ratification of the TRIPS agreement, UPOV members were mostly western European countries and "Western offshoots" such as the United States, Australia, Canada and South Africa. After the ratification of the TRIPS agreement in 1994, countries from Latin America, Africa, Asia as well as former socialist economies of Eastern Europe have been joining the Convention.

This heterogeneity in the evolution of the patterns of legislation suggests that the construction of an indicator of IPRs for plant varieties may contribute to enhancing our understanding of the relationship between IPRs and innovation. Of course, the 


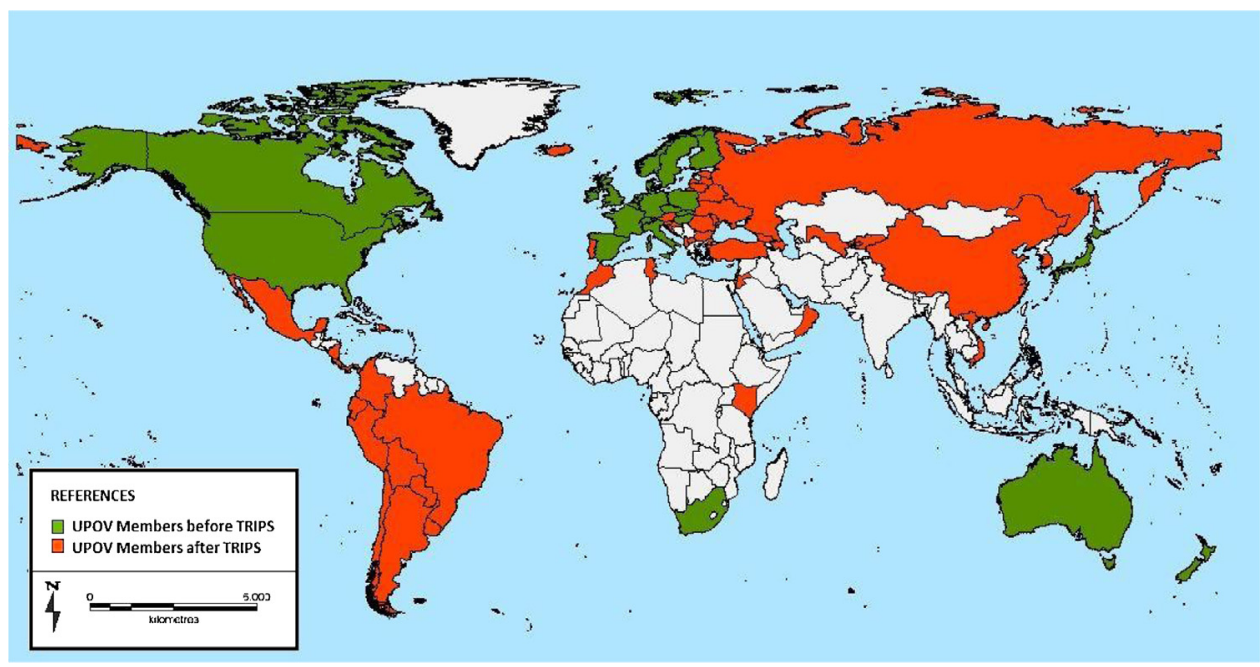

Fig. 2. Members of UPOV Convention before and after TRIPS agreement.

construction of a synthetic index of worldwide IP protection for plant varieties may come at the price of neglecting specific historical events or country-specific institutional details, but, conversely, it has the advantage of providing us with a comparative comprehensive view of the main trends of IP protection in this domain.

\subsection{Construction of the index}

The index is based on a comparative historical perspective and it covers the period 1961-2011. We have constructed the index for the 69 countries that by 2011 had signed the UPOV Convention. ${ }^{8}$ The countries included in our sample are characterized by a rather similar basic legal framework regulating plant variety protection, which follows the general guidelines established by UPOV. We have constructed the index considering the elements that, within this common framework, tend to vary more from country to country and over time.

Our approach is similar to the method used by Ginarte and Park (1997) to measure the strength of patent protection. Our index consists of five components that are together supposed to determine the overall strength of IP protection for plant varieties prevailing in each country. The five components of the index are: (i) ratification of UPOV Conventions; (ii) farmers' exception; (iii) breeder's exception; (iv) protection length; and ( $v$ ) patent scope. The components of the index are set out in Table 1.

\subsubsection{Ratification of UPOV Conventions}

This component considers whether a country has adhered to the subsequent revisions of the UPOV Convention: the "1961/1972 Act" which is the International Convention for the Protection of New Varieties of Plants of December 2, 1961, as amended by the Additional Act of November 10,1972; the "1978 Act", which refers to the Act of October 23, 1978; and the "1991 Act", which is the Act of March 19, $1991 .^{9}$ Two main reasons justify consideration of this component. First, we can argue that the first signatory countries were willing to provide a sui generis system of IP protection for

\footnotetext{
${ }^{8}$ It is worth noting that a set of countries provide protection for plants but are not UPOV members (e.g., India). These countries are not included in our database.

9 The first UPOV Convention was adopted in 1961 and amended in 1972. The amendments modified, among other issues, the majority rules required for the decisions of the Council; the funding structure of the Convention; the signature, the ratification and accession; the entry into force; and the reservations. Thus, unlike the following revisions (1978 and 1991), the 1972 amendment did not modify the type of IPRs proposed by the 1961 Convention.
}

Table 1

The structure of the index.

\begin{tabular}{|c|c|c|c|}
\hline & Component & $\begin{array}{l}\text { Score } \\
\text { range }\end{array}$ & $\begin{array}{l}\text { Normalized } \\
\text { score }\end{array}$ \\
\hline \multirow[t]{4}{*}{1} & Ratification of UPOV Conventions & $0-3$ & {$[0,1]$} \\
\hline & 1961 & $0-1$ & \\
\hline & 1978 & $0-1$ & \\
\hline & 1991 & $0-1$ & \\
\hline \multirow[t]{2}{*}{2} & Farmers' exception & $0-1$ & {$[0,1]$} \\
\hline & Not considered & $0-1$ & \\
\hline \multirow[t]{2}{*}{3} & Breeders' exception & $0-1$ & {$[0,1]$} \\
\hline & Essentially derived variety & $0-1$ & \\
\hline \multirow[t]{2}{*}{4} & Duration & $0-35$ & {$[0,1]$} \\
\hline & At most 35 years & $0-35$ & \\
\hline \multirow[t]{7}{*}{5} & Patent scope & $0-5$ & {$[0,1]$} \\
\hline & Food & $0-1$ & \\
\hline & Plant and animals & $0-1$ & \\
\hline & Microorganisms & $0-1$ & \\
\hline & Pharmaceuticals & $0-1$ & \\
\hline & Plant varieties & $0-1$ & \\
\hline & Index & $0-45$ & {$[0,5]$} \\
\hline
\end{tabular}

plant varieties at a relatively early stage and, relatedly, they had more time to construct and refine the institutional set-up necessary to provide and enforce this type of IPRs. Second, each revision of the Convention introduced several amendments that progressively set a stricter number of requirements for PBRs regulations.

This component of the index is constructed as follows. A country adhering to the three Conventions or Acts is assigned a total score of 3 ( 1 for each Convention). The first countries entering the UPOV signed the 1961/1972 Convention and later most of them ratified all of the subsequent revisions. Yet, a country entering the UPOV Convention after the enactment of the second or third revision can decide which specific version of the Convention to adopt. For example, Argentina became member of the UPOV in 1995 when the 1991 Act was already available, but decided to adhere to the 1978 Convention. However, since 1998, new members are not allowed to enter the UPOV, 1978 Convention and can only join the last revision of the Convention (1991). Accordingly, in the construction of the index, we have assumed that a country signing the last Convention, by default, has also adhered to the previous ones. For instance, Bulgaria became a member of UPOV in 1998 and adhered to the 1991 Act. Hence, we assign to this country, since 1998, a score of 1 for each revision of the Convention, amounting to a total score of 3. We assign Argentina a score of 2 since 1995 because so far, this country has only signed the "1961/1972" and the 1978 Conventions. 


\subsubsection{Farmers' exception}

This component considers the so-called farmers' privilege or farmers' exception, which states that farmers have the right to freely use the product of harvests obtained from seeds of any protected plant variety for the purpose of reproduction in their farms. In some cases, this exception also contemplates the rights of farmers to sell the product of their harvest as seeds to other parties. The exception was compulsory in the first two Acts of the UPOV and became optional in the 1991 Act. Some countries have been limiting this exception while others have forbidden the application of this clause to genetically modified seeds. As a result, it should be noted that the practice of saving seeds has almost disappeared in some countries, such as the United Sates, while in others it is still widespread. For the construction of this component of our index, we assume that there is no farmers' exception when the legislation explicitly claims that the practice is not allowed in the country in question or when its application requires monetary compensation for the breeder. The farmers' exception obviously represents a limitation to the strength of IP protection. Accordingly, we assign a score of 0 to countries that uphold the exception and a score of 1 to countries that do not uphold it.

\subsubsection{Breeders' exception}

This component considers the so-called breeders' exception, which states that the exclusion right does not extend to the use of a plant variety for experimental or research purposes by other breeders. Clearly, this exemption seeks to protect innovations without preventing improvements and development of new plant varieties. The breeders' exception is compulsory in all of the Conventions. However, the 1991 Act introduced the concept of "essentially derived variety", which resulted in a limitation of the scope of the breeders' exception. According to the Act, an "essentially derived variety" is one that is clearly distinguishable from the initial one but retains its essential characteristics. When this limitation is introduced, a breeder working on the development of a variety considered "essentially derived" needs the authorization of the owner of the initial variety even for its experimental use. In practical terms, all countries contemplate the breeders' exception, but not all of them have adopted the "essentially derived variety" doctrine. Accordingly, for this component we assign a score of 1 whenever a country's legislation has adopted the doctrine of "essentially derived variety" and a score of 0 otherwise.

\subsubsection{Protection length}

This component considers the duration of the right. The legislation on plant variety protection often differentiates between plant varieties, and trees and vines, with the former receiving a shorter term of protection. For the construction of this component of the index, when a country applies this discrimination, we have decided to consider the longer protection. The $1961 / 1972$ and 1978 Conventions suggested a minimum protection period of 15 years for plant varieties and 18 years for vines and trees. However, any country may adopt a longer period of protection (UPOV, 1961, 1978). Meanwhile, the last UPOV Convention states that PBRs should be granted with a duration of at least 20 years for plant varieties and 25 years for vines and trees (UPOV, 1991). The score for this component is simply the number of years of protection contemplated in the relevant national legislation.

\subsubsection{Patent scope}

This component considers the issue of patenting in five specific domains related to plant breeding. The intuition underlying this component is to characterize the "broader attitude" of the legislation of a specific country towards the general issue of IP protection for plant varieties, beyond the immediate effect of plant breeders' rights. Accordingly, we consider the scope of
Table 2

Factor analysis of the index components (factor loadings and unique variances).

\begin{tabular}{lll}
\hline & Factor loading & Uniqueness \\
\hline 1. Ratification of UPOV Conventions & 0.9041 & 0.1826 \\
2. Farmers' exception & 0.7431 & 0.4478 \\
3. Breeders' exception & 0.7326 & 0.4633 \\
4. Duration of right & 0.9059 & 0.1794 \\
5. Patent scope & 0.8022 & 0.3564
\end{tabular}

Note: number of observations: 2992; LR test (independent vs. saturated). $\chi^{2}(10)=8288.04 ;$ Prob $>\chi^{2}=0.000$.

patentability in domains which are linked with plant breeding and agriculture. More specifically, the fields we consider are: (i) food, which obviously processes products from agriculture; (ii) plant and animals; ${ }^{10}$ (iii) microorganisms, which are closely related with the development of biotechnology and its application to plant breeding; (iv) pharmaceutical products because this industry may also rely on biodiversity and genetic resources; and (v) plant varieties (either sexually or asexually reproduced). ${ }^{11}$ Many countries regarded some or all of these domains as not patentable subject matter, for reasons going under the heading of "public order, morality, health or national interest or security". More recently, the TRIPS agreement made it compulsory to declare patentable microorganisms, non-biological and microbiological processes for the production of plant varieties. Currently, only four countries the United States, Australia, Japan and South Korea - consider specific plant varieties as patentable subject matter. For each of these domains we assign a score of 1 when they are declared, explicitly or implicitly, as patentable subject matter in the patent laws of the country in question.

\subsection{Sources and construction of the index}

The information for the construction of the index was retrieved by examining the legislation of each country, which was available online in many cases. All websites were accessed between July and December 2012. In addition, we have also interviewed experts of different countries in order to check or obtain missing information.

For data regarding the ratification of the UPOV Conventions, the source of information is the official Convention notifications documents, which indicates the different ratifications made by each country. These documents are available at the UPOV website (upov.int/upovlex/en/notifications.jsp). Information regarding early signatory countries can be found in Heitz (1987).

The information concerning the duration of protection and the exceptions was extracted from the national legislation that is available on these websites: WIPO Intellectual Property Laws and Treaties Database (www.wipo.int/wipolex/en/); UPOV Lex (www.upov.int/upovlex/en/); Farmers' Rights Database (www.farmersrights.org/database); and the World Law Guide (www.lexadin.nl/wlg/). For some countries, data regarding exceptions were extracted from the "Questionnaire on Exceptions and Limitations to Patents Rights", conducted by WIPO (www.wipo.int/scp/en/exceptions/).

Finally, for the identification of the patent scope, the main information was generously provided to us by Walter Park, who has shared the data used in Ginarte and Park (1997) and Park (2008). For the most recent period and for the countries that were missing in the original data on patent scope, we have used the follow-

\footnotetext{
10 This component covers legislation contemplating the patenting of plants and animals when the invention is not limited to a specific variety.

11 In the construction of the index we distinguish systems that contemplate patenting of "generic" plant and animals, from systems that contemplate the option of patenting a specific plant variety.
} 
Table 3

Spearman's rank correlation matrix of the index components.

\begin{tabular}{|c|c|c|c|c|c|}
\hline & 1 & 2 & 3 & 4 & 5 \\
\hline 1. Ratification of UPOV Conventions & 1 & & & & \\
\hline 2. Farmers' exception & $0.8670^{* * *}$ & 1 & & & \\
\hline 3. Breeders' exception & $0.6161^{* * *}$ & $0.4320^{* * *}$ & 1 & & \\
\hline 4. Duration of right & $0.7924^{* * *}$ & $0.7474^{* * *}$ & $0.6844^{* * *}$ & 1 & \\
\hline 5. Patent scope & $0.6561^{* * *}$ & $0.6338^{* * *}$ & $0.4572^{* * *}$ & $0.6581^{* * *}$ & 1 \\
\hline
\end{tabular}

${ }^{* * *}$ All coefficients are significant at the $1 \%$ probability level.

ing sources: Lerner (2002), WIPO (2009), and the official national documents contained in the WIPO Intellectual Property Laws and Treaties Database (www.wipo.int/wipolex/en/) and The World Law Guide (www.lexadin.nl/wlg/).

The value of each of the five components, assigned with the scoring system described above, was transformed into a new indicator ranging between 0 and $1 .{ }^{12}$ This was done using the formula:

$X_{i t}=\frac{x_{i t}-\min \left(x_{i}\right)}{\max \left(x_{i}\right)-\min \left(x_{i}\right)}$

where $x_{i t}$ is the original score of each component $i=1, \ldots, 5$ of the index for each year $t=1969, \ldots, 2011$ and $X_{i t}$ is the value rescaled in the interval $[0,1]$. The rescaled values of the components were added and, as a result, the value of the index for a given country in a given year ranges between 0 and 5 with higher scores indicating a stronger system of IP protection for plant varieties. In this way, our index is constructed as the simple sum of the different components and, therefore, it implicitly assigns an equal weight to each of them. To check the suitability of this approach for aggregating the various components of the index, we have carried out two robustness checks.

First, we have studied the components by means of factor analysis. We have used a principal component factor estimation, which has been shown to be relatively robust to different assumptions on the distribution of the data. Table 2 presents the results. The Kaiser criterion suggested that one factor, with eigenvalue greater than 1 , should be retained and this factor explains $67.41 \%$ of the total variance. ${ }^{13}$

As expected, all the factor loadings are high, meaning that they are all relevant in defining the factor's dimensionality. The degree of uniqueness is very low for all the factor loadings, which implies that they are all relevant in the factor model and that there are few unexplained factors affecting the relationships among them. Table 3 contains a matrix of Spearman's rank correlations of the components of the index, showing that they are highly correlated and significant.

Second, we have constructed another version of the index using the Borda count method, which is an aggregation method that entails the calculation of the ranking of each country according to each individual indicator. The final index is then constructed simply as the sum of the resulting rankings (Joint Research Centre-European Commission, 2008). Because it is based on rankings, this approach considers only the ordinal information when aggregating the different components and, as such, it is less affected by outliers. ${ }^{14}$ This approach is a useful additional robustness check because it provides an alternative way of normalizing and

\footnotetext{
12 This methodology is similar to the one adopted until 2011 by the United Nations Development Programme (UNDP) to construct the Human Development Index. See: Anand and Sen (1994).

13 In addition, other estimation methods, such as principal factor and iterated principal factors, generated factors with very similar loadings accounting for a similar share of total variance.

${ }^{14}$ For an example of the application of the Borda count ranking to the aggregation of quality of life indices, see Dasgupta and Weale (1992).
}

Table 4

Spearman's rank correlation matrix of different versions of the index.

\begin{tabular}{llll}
\hline Index & 1 & 2 & 3 \\
\hline 1. Unweighted index & 1 & & \\
2. Weighted index using factor analysis & $0.9979^{* * *}$ & 1 & 1 \\
3. Weighted index using Borda count & $0.9810^{* * *}$ & $0.9817^{* * *}$ & 1 \\
\hline
\end{tabular}

*** All coefficients are significant at the $1 \%$ probability level.

Table 5

Spearman's correlation between the index of IP protection for plant varieties and other IPRs measures.

\begin{tabular}{ll}
\hline Indicator and source & $\begin{array}{l}\text { Correlation with } \\
\text { plant variety } \\
\text { protection index }\end{array}$ \\
\hline $\begin{array}{l}\text { Patent index (1961-2005) (Ginarte and Park, 1997; } \\
\quad \text { Park, 2008) }\end{array}$ & $0.8335^{* * *}$ \\
$\begin{array}{l}\text { Index of Intellectual Property Rights in Pharmaceutical } \\
\text { Innovations (1961-2005) (Liu and La Croix, 2014) }\end{array}$ & $0.7935^{* * *}$ \\
$\begin{array}{l}\text { Intellectual property protection (2006-2011) (The } \\
\quad \text { World Economic Forum) }\end{array}$ & $0.1748^{* * *}$ \\
$\begin{array}{l}\text { Global Competitiveness Index (2006-2011) (The } \\
\quad \text { World Economic Forum) }\end{array}$ & $0.2513^{* * *}$ \\
$\begin{array}{l}\text { Intellectual Property Rights (2007-2011) (Property } \\
\text { Rights Alliance) }\end{array}$ & $0.2191^{* * *}$ \\
$\begin{array}{l}\text { International Property Rights Index (2007-2011) } \\
\quad \text { Property Rights Alliance) }\end{array}$ & $0.1950^{* * *}$ \\
\hline *** All coefficients are significant at the 1\% probability level. &
\end{tabular}

aggregating the five components of the index apart from the unweighted sum of components and the factor analysis.

Table 4 shows that the indices constructed using the unweighted sum of the components. Those constructed using factor analysis and the Borda count approach are all highly correlated. The original unweighted index has a Spearman's rank correlation coefficient of 0.9995 with the weighted index constructed using factor analysis, and a Spearman's rank correlation coefficient of 0.9817 with the index built with the Borda count method. These high correlations imply that even if the absolute values of the index may change according to the aggregation method, the overall rankings remain very stable. Therefore, for the sake of simplicity, in the rest of this work, we will use the unweighted index constructed by the simple addition of the normalized values of the five components.

It is also instructive to compare the index with alternative measures of IP protection and indicators of the overall institutional set-up of a country, which comprise IP protection as a component. Table 5 contains the Spearman's rank correlation coefficients of our plant variety protection index and the following indicators: (i) the patent protection index of Ginarte and Park (1997) and Park (2008); (ii) the Index of Intellectual Property Rights in Pharmaceutical Innovations created by Liu and La Croix (2014); (iii) an Intellectual Property Rights Index, ${ }^{15}$ which is part of the

\footnotetext{
15 This index is constructed on the basis of surveys asking how those interviewed would rate IP protection, including anti-counterfeiting measures, in their country [1 = very weak; 7 = very strong].
} 
Table 6

Summary statistics of the index by decades.

\begin{tabular}{|c|c|c|c|c|c|c|c|c|}
\hline Period & $\%$ Obs $=0$ & $\%$ Obs $>0$ & Mean without zeros & Mean & Sd & Min & Max & Skew \\
\hline $1961-1970$ & 44.51 & 55.49 & 0.40 & 0.23 & 0.32 & 0 & 1.85 & 2.35 \\
\hline $1971-1980$ & 37.26 & 62.75 & 0.70 & 0.44 & 0.59 & 0 & 2.45 & 1.38 \\
\hline 1981-1990 & 32.38 & 67.62 & 1.11 & 0.75 & 0.87 & 0 & 3.32 & 0.89 \\
\hline $1991-2000$ & 8.58 & 91.42 & 1.71 & 1.56 & 1.14 & 0 & 4.66 & 0.40 \\
\hline $2001-2011$ & 0 & 100 & 2.95 & 2.95 & 1.02 & 0.4 & 4.66 & -0.43 \\
\hline $1961-2011$ & 21.59 & 78.41 & 2.02 & 1.35 & 1.36 & 0 & 4.66 & 0.73 \\
\hline
\end{tabular}

(iv) Global Competitiveness Index ${ }^{16}$ developed by the World Economic Forum (www.weforum.org); (v) an indicator of Intellectual Property Rights ${ }^{17}$ protection, which is part of the (vi) International Property Rights Index ${ }^{18}$ developed by the Property Rights Alliance (www.propertyrightsalliance.org/).

Table 5 shows that plant variety index is positively and highly correlated with the patent protection index of Ginarte and Park (1997) and Park (2008) and with the Index of Intellectual Property Rights in Pharmaceutical Innovations constructed by Liu and La Croix (2014). The correlation is also positive and significant but remarkably lower with indicators that are broader in their coverage because they consider IPRs together with institutional and political factors, as well as the security of property rights in other domains.

All this indicates that the strength of the IP legislation on plant varieties is indeed broadly correlated with legislation prevailing in other fields. This suggests that the overall legislation of a country concerning IP protection matters is possibly characterized by a general outlook concerning the functioning of markets and property rights. This outlook provides a fundamental imprint for shaping IPRs systems in different domains. However, it is also clear that sector specificities matter and that they are reflected in the related IPRs measures. Therefore, by capturing different aspects of IP protection policy, the indicators of Table 5 complement each other.

\section{The worldwide evolution of IP protection in plant varieties}

In Appendix (Table A1), we provide the detailed scores of the index of IP protection for plant varieties for each country in our sample at five-year intervals. In this section, we examine the worldwide evolution of IP protection in plant varieties as portrayed in our index. Table 6 contains summary statistics.

The summary statistics show that the mean of the index has been increasing over time (even when not considering the years in which countries have a value of zero, which means that there was no IP protection available at that time). Meanwhile, the distribution has shifted from a positively skewed to a negatively skewed one in the last decade, indicating that most countries currently have an index score that is above the mean. These two tendencies are probably an outcome of the increased strength of protection in countries that were early signatories of UPOV and of the adoption of IPRs systems characterized by relatively strong levels of protection by countries accessing UPOV in the most recent period.

Fig. 3 illustrates the strengthening of IP protection using boxplots. Countries have been classified in two groups: developed and

\footnotetext{
16 Competitiveness is defined in this index as the set of institutions, policies, and factors that determine the level of productivity of a country and its growth potential (Sala-I-Martin et al., 2012).

17 It considers Protection of Intellectual Property Rights, Patent Protection, Copyright Piracy, and Trademark Protection.

${ }_{18}$ This index has the following dimensions: Legal and Political Environment, Physical Property Rights, and Intellectual Property Rights.
}

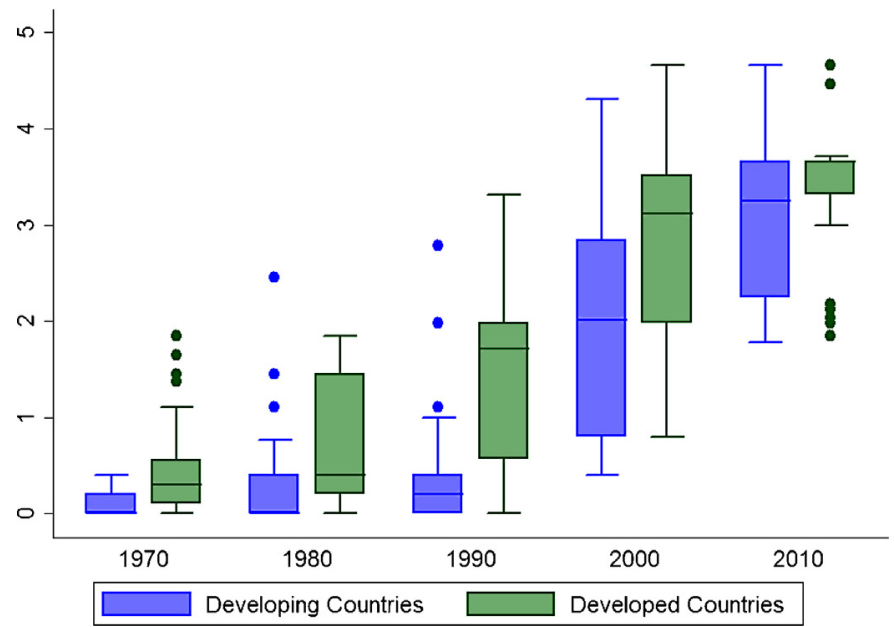

Fig. 3. Evolution of the IP protection index according to development level

developing countries (See Table A2 in Appendix). ${ }^{19}$ For both groups of countries, Fig. 3 shows a growth of the index combined with a decrease of its dispersion, especially in the last decade. While in the first three decades we observe an increase in the index for developed countries, after the 1990s, there is also a rapid increase in the index of developing countries. This process is probably driven by the signing of the TRIPS agreement.

If we examine the evolution of the index according to the income level of the countries, we also find that the strength of IP protection for plant varieties has been growing at different paces (Table 7). ${ }^{20}$ The initial gap between high income countries and the rest has been narrowing (especially because middle- and low-income countries have been progressively tightening their IPRs systems).

It is also interesting to examine the evolution of the index from a geographical point of view (Table 8). The level of IP protection for plant varieties has been increasing over time in all of the regions, but we observe some differences in the initial positions. In this case, in line with the evidence discussed above, we observe that some regions (mostly comprising developed and high income countries), such as western Europe, North America and Oceania, have relatively

\footnotetext{
19 The distinction between developed and developing countries is taken from United Nations (2012). The classification is based on a number of criteria comprising GNI per capita, a "human assets" index and an "economic vulnerability" index. See Table A2 in Appendix.

20 Following United Nations (2012), we have classified countries in three groups according to their income levels: (i) high-income; (ii) middle-income, which corresponds to the category "upper middle-income"; (iii) low-income, which comprises the categories of both "lower middle-income" and "low-income". The threshold levels of GNI per capita for defining these categories are defined following indications of the World Bank. For the year 2011, countries with less than $\$ 3975$ gross national income (GNI) per capita are classified as low-income countries, those with GNI per capita between $\$ 3976$ and $\$ 12,275$ as middle-income countries, and those with income greater than $\$ 12,276$ as high-income countries. See Table A2 in Appendix.
} 
Table 7

Evolution of the IPRs index for plant varieties by income level.

\begin{tabular}{|c|c|c|c|c|c|}
\hline Country & 1961-1970 & 1971-1980 & 1981-1990 & 1991-2000 & $2001-2011$ \\
\hline High income (33) & 0.36 & 0.68 & 1.19 & 2.06 & 3.12 \\
\hline Middle income (24) & 0.09 & 0.16 & 0.24 & 1.12 & 2.72 \\
\hline Low income (12) & 0.11 & 0.18 & 0.24 & 1.10 & 2.82 \\
\hline
\end{tabular}

Note: see Appendix for the classification of countries according to their income and development stage.

Table 8

Evolution of the IPRs index for plant varieties by world region.

\begin{tabular}{|c|c|c|c|c|c|}
\hline Country & $1961-1970$ & $1971-1980$ & 1981-1990 & $1991-2000$ & $2001-2011$ \\
\hline Asia & 0.42 & 0.48 & 0.68 & 1.24 & 2.81 \\
\hline Eastern and central Europe & 0.08 & 0.16 & 0.34 & 1.37 & 3.34 \\
\hline Latin America and the Caribbean & 0.09 & 0.12 & 0.14 & 1.06 & 2.26 \\
\hline Middle East and North Africa & 0.15 & 0.51 & 0.72 & 1.33 & 3.03 \\
\hline North America & 0.53 & 0.79 & 1.47 & 2.59 & 2.85 \\
\hline Oceania & 0.21 & 0.20 & 1.18 & 2.61 & 2.92 \\
\hline Sub-Saharan Africa & 0.40 & 0.86 & 1.50 & 1.96 & 2.58 \\
\hline Western Europe & 0.35 & 0.75 & 1.33 & 2.19 & 3.08 \\
\hline
\end{tabular}

high levels of protection at the beginning of the period considered here. The same situation seems to prevail as well in Asia and Sub-Saharan Africa. Other regions, such as Latin America, the Middle East and North Africa, are instead characterized by initial low levels of protection, increasing at a slow pace until the 1990s and accelerating thereafter.

We should note that countries belonging to the Soviet Union, the Soviet block and the former Yugoslavia are included in our sample since the 1990s when they became "independent" states. Before the 1990s, these countries are not considered because either they did not have IP protection laws or, when they did, these were characterized by rather different and non-comparable institutional arrangements. For instance, the IPRs system prevailing in the Soviet Union was comprised of two main parts: the granting of inventor certificates for domestic inventors, and a patent system that was only formally similar to that of Western countries (Blair, 1973). ${ }^{21}$ A similar dual system prevailed also in China. However, the practical significance of these IP protection systems was marginal. In the Chinese case, it was only at the beginning of the 1980s that a system of IP protection similar to those prevailing in Western countries was gradually put in place (Ganea et al., 2009).

\section{The determinants of IP protection for plant varieties}

In this section, we carry out an econometric exercise that examines the correlation of our index with some country characteristics in a multivariate setting. We consider a set of covariates comprising specific country features that may affect the IPRs system for plant varieties: the general development level, institutional and political factors, the relevance of agriculture for the economy, and openness. In addition, we include a dummy for the ratification of the TRIPS agreement. See Table A3 in Appendix for the descriptive statistics of the variables.

Index $_{i t}=\alpha_{i}+\beta_{x} X_{i t}+\mu_{i t}$,

where $X_{i t}$ is a set of covariates (see Table A3 in Appendix for the descriptive statistics) and $\mu_{i t}$ is the error term.

We use two indicators of economic development: (i) GDP per capita (in log), retrieved from the Maddison Project (www. ggdc.net/maddison/maddison-project/index.htm) and (ii) the

21 A major distinction between an inventor's certificate and a patent is that the former is assigned to the state, while the patent is owned by the inventor or the party to whom it was assigned. urbanization rate measured by the proportion of urban population over rural population, provided by FAOSTAT (www.faostast fao.org).

Another relevant country characteristic that may determine the level of IP protection for plant varieties is obviously the role of agriculture in the economy. To examine this effect we consider a variable developed by FAOSTAT: the agricultural export value index (in log), which represents the change in the current values of export FOB (free on board) expressed in US dollars.

We use two variables to characterize the institutional and political environment of each country: (i) the index of political system developed by Marshall et al. (2010) for the Polity IV Project, which provides annual information on the governance characteristics and level of democracy of each country, and (ii) the Index of Economic Freedom developed by The Heritage Foundation (www.heritage.org), which measures the following features of the institutional environment: business freedom, trade freedom, fiscal freedom, government spending, monetary freedom, investment freedom, financial freedom, property rights, freedom from corruption, and labour freedom. The correlation matrix of Table 9 shows that these two variables are positively correlated with GDP per capita. At the same time, however, they are not highly correlated among themselves because they presumably capture different dimensions of the political and institutional framework.

Additionally, we include an indicator of openness to trade extracted from the Penn World Table 7.1 (Heston et al., 2012). This indicator is the total trade of a country (exports plus imports) divided by its real GDP in constant prices of 2005 (in log). This indicator is considered in the estimations because economic theory usually argues that openness to trade facilitates technology transfer and promotes innovation.

Finally, we introduce a dummy variable for the ratification of the TRIPS agreement, expecting that this would capture the effect of the agreement on the strength of IPRs systems. This variable assumes the value of 1 since the year in which a country has ratified the TRIPS agreement. It should be noted that the TRIPS has established different time schedules for compliance according to the development level of the country.

Because we are concerned with a group of heterogeneous countries in terms of development levels, simple correlations may actually conceal more complex relations among the variables. Therefore, we estimate models both for the complete panel dataset and for two sub-samples of developed countries (DCs) and developing countries (LDCs) in order to identify possible divergent patterns of behaviour. 
Table 9

Correlation matrix for variables used in the econometric exercises.

\begin{tabular}{|c|c|c|c|c|c|c|c|}
\hline Independent variable & 1 & 2 & 3 & 4 & 5 & 6 & 7 \\
\hline 1. GDP per capita (log) & 1 & & & & & & \\
\hline 2. Urban population/rural population & 0.4505 & 1 & & & & & \\
\hline 3. Index of political system & 0.5858 & 0.3364 & 1 & & & & \\
\hline 4. Economic freedom & 0.6193 & 0.2083 & 0.4405 & 1 & & & \\
\hline 5. agriculture export value index (log) & 0.1561 & 0.1456 & 0.1911 & 0.3959 & 1 & & \\
\hline 6. Openness to trade (log) & 0.0315 & -0.1202 & -0.0267 & 0.3116 & 0.3959 & 1 & \\
\hline 7. Ratification of the TRIPS agreement & 0.1799 & 0.1866 & 0.2458 & 0.4255 & 0.5628 & 0.3485 & 1 \\
\hline
\end{tabular}

Table 10

Determinants of IP protection in plant varieties (fixed effects estimates).

\begin{tabular}{llll}
\hline Model & $(1)$ & $(2)$ & $(3)$ \\
Sample & FS & DC & LDC \\
\hline GDP per capita $(\log )$ & $0.339^{* * *}$ & $0.704^{* * *}$ & -0.078 \\
& $(0.091)$ & $(0.176)$ & $(0.099)$ \\
Urban pop./rural pop. & $0.141^{* * *}$ & $0.324^{* * *}$ & $0.184^{* * *}$ \\
& $(0.025)$ & $(0.054)$ & $(0.027)$ \\
Index of political system & -0.000 & 0.006 & -0.007 \\
& $(0.004)$ & $(0.007)$ & $(0.005)$ \\
Economic freedom & $0.108^{* * *}$ & $0.257^{* * *}$ & $0.054^{* *}$ \\
& $(0.021)$ & $(0.038)$ & $(0.024)$ \\
Agr. exp. value index $(\log )$ & $0.125^{* * *}$ & $-0.132^{* *}$ & $0.221^{* * *}$ \\
& $(0.034)$ & $(0.053)$ & $(0.042)$ \\
Openness (log) & $0.307^{* * *}$ & $1.038^{* * *}$ & $-0.289^{* * *}$ \\
& $(0.078)$ & $(0.141)$ & $(0.091)$ \\
Dummy for TRIPS & $1.106^{* * *}$ & $0.607^{* * *}$ & $1.363^{* * *}$ \\
Constant & $(0.047)$ & $(0.072)$ & $(0.058)$ \\
& $-4.761^{* * *}$ & $-11.471^{* * *}$ & 0.856 \\
Observations & $(0.746)$ & $(1.456)$ & $(0.799)$ \\
$R^{2}$ & 1873 & 905 & 968 \\
Number of countries & 0.695 & 0.745 & 0.703 \\
& 55 & 25 & 30
\end{tabular}

Note: the dependent variable is the index of IP protection for plant varieties. Standard errors in parentheses.

** Significance level, $p<0.05$.

*** Significance level, $p<0.01$.

Exploiting the panel structure of the data we have carried out both fixed effects (FE) and random effects (RE) estimations. The Hausman test rejected the null hypothesis that individual effects are random. Thus, Table 10 presents the results of the fixed effects estimation method for the full sample and the two sub-samples. ${ }^{22}$

In the estimation for the full sample(FS), all of the variables were found to be positively and significantly related with the level of IP protection for plant varieties, except for the index of political system, which is not significant. Disaggregating the samples according to development level, some important differences emerge. For the estimation restricted to DCs, the GDP per capita, level of urbanization, economic freedom and openness to trade appear positively and significantly correlated with the index of IP protection. Like in DCs, the level of urbanization and economic freedom were found to be positive and significant. Instead, the GDP per capita was not significant. For two variables - the index of agricultural exports value and openness to trade - the effects are significant both in DCs and LDCs, but their impact is opposite. This may reflect the greater importance that exports of agricultural products have for developing countries. Instead, in developed countries the general degree of openness seems to be correlated with a stronger degree of IP protection. All this suggests that IPR regimes may be shaped by different economic factors in developing and developed countries. It is interesting to note that the index of political system turned out to be not significant in all three models. Finally, the dummy for the signing of the TRIPS agreement is positive and significant for the

\footnotetext{
22 We have also estimated the models with lagged covariates obtaining analogous results in terms of significance and size of the coefficients.
}

full sample and both sub-samples. Overall, our econometric analysis suggests that there might be non-linear relations among the level of IP protection and variables such as the GDP per capita, the index of agricultural exports, and openness to trade.

\section{IPRs in plant breeding and agricultural production}

In this section, we provide a first example of how our index can be used to study the effect of IP protection on agricultural production in a cross-country analysis. The effect of IP protection on agricultural innovation, productivity and development is not obvious because the empirical literature offers mixed evidence.

Several authors have found only very weak or no evidence supporting the notion that IPRs are effective in stimulating investments leading to innovation in plant varieties and productivity growth (Alston and Venner, 2002; Léger, 2005; Louwaars et al., 2005). ${ }^{23}$ Conversely, other authors have reached opposite conclusions. For instance, using data for 103 countries, Payumo et al. (2012) have studied the relation between the strength of IPRs systems and agricultural development, which is "proxied" by the agricultural gross domestic product. They found a positive correlation between these two variables both for developed and developing countries. ${ }^{24}$

In these exercises, most of the literature uses the patent index developed by Ginarte and Park (1997) even if this index provides a more general indicator of IP protection in the manufacturing sector. In contrast, our index has been developed to characterize the strength of IP protection in agriculture and, thus, we believe that it may capture other specific effects of IPRs on agricultural production.

As the dependent variable we use the log of agriculture value added in constant US dollars of 2005. Agricultural value added is computed as the net output of sectors 1-5 of the International Standard Classification (ISIC, revision 3), and it is available at the World Development Indicators (WDI) (databank.worldbank.org/).

To study the effect of IPRs, we use our index of IP protection for plant varieties (lagged_ind) with a one-year lag in order to address potential endogeneity between agricultural value added and the index..$^{25}$ As covariates, we use a set of control variables usually considered as determinants of agricultural productivity and growth

\footnotetext{
23 In a recent study, Olmstead and Rhode (2008) documented the dramatic rate of progress in plant breeding attained in the US during the nineteenth century, well before the introduction of any system of formal IPRs.

24 Payumo et al. (2012) used the index of Ginarte and Park (1997) to measure the strength of IPRs in agriculture. Their model is broadly similar, but not fully comparable to the one we estimate in this section. It is interesting that by using an indicator that is, in principle, more alert to the specificities of IP protection in the agricultural sector we obtain different results.

25 In addition, to address a potential endogeneity issue between agricultural value added and all the covariates, we have estimated the models of Table 11 using covariates with several lags and we obtained analogous results in terms of sign and size of the coefficients. The only visible difference is that the size of the coefficients decreases with the number of lags as one would have expected.
} 
Table 11

Agricultural value added and IPRs. Fixed effects estimation results.

\begin{tabular}{|c|c|c|c|c|c|c|c|c|c|}
\hline $\begin{array}{l}\text { Model } \\
\text { Sample }\end{array}$ & $\begin{array}{l}(1) \\
\text { FS }\end{array}$ & $\begin{array}{l}\text { (2) } \\
\text { DC }\end{array}$ & $\begin{array}{l}\text { (3) } \\
\text { LDC }\end{array}$ & $\begin{array}{l}(4) \\
\mathrm{FS}\end{array}$ & $\begin{array}{l}\text { (5) } \\
\text { DC }\end{array}$ & $\begin{array}{l}\text { (6) } \\
\text { LDC }\end{array}$ & $\begin{array}{l}(7) \\
\text { FS }\end{array}$ & $\begin{array}{l}(8) \\
\text { DC }\end{array}$ & $\begin{array}{l}\text { (9) } \\
\text { LDC }\end{array}$ \\
\hline lagged_ind & $\begin{array}{l}0.026^{* * *} \\
(0.006)\end{array}$ & $\begin{array}{l}0.033^{* * *} \\
(0.008)\end{array}$ & $\begin{array}{l}0.003 \\
(0.009)\end{array}$ & $\begin{array}{l}0.026^{* * *} \\
(0.006)\end{array}$ & $\begin{array}{l}0.032^{* * *} \\
(0.008)\end{array}$ & $\begin{array}{l}0.002 \\
(0.009)\end{array}$ & $\begin{array}{l}0.031^{* * *} \\
(0.012)\end{array}$ & $\begin{array}{l}0.010 \\
(0.015)\end{array}$ & $\begin{array}{l}0.020 \\
(0.023)\end{array}$ \\
\hline schoo & $\begin{array}{l}0.056^{* * *} \\
(0.008)\end{array}$ & $\begin{array}{l}0.045^{* * *} \\
(0.011)\end{array}$ & $\begin{array}{l}0.059^{* * *} \\
(0.014)\end{array}$ & $\begin{array}{l}0.059^{* * *} \\
(0.008)\end{array}$ & $\begin{array}{l}0.046^{* * *} \\
(0.011)\end{array}$ & $\begin{array}{l}0.060^{* * *} \\
(0.014)\end{array}$ & $\begin{array}{l}0.053^{* * *} \\
(0.013)\end{array}$ & $\begin{array}{l}0.117^{* * *} \\
(0.024)\end{array}$ & $\begin{array}{l}-0.018 \\
(0.023)\end{array}$ \\
\hline irrig & $\begin{array}{l}0.374^{* * *} \\
(0.084)\end{array}$ & $\begin{array}{l}0.396^{* * *} \\
(0.094)\end{array}$ & $\begin{array}{l}-0.186 \\
(0.216)\end{array}$ & $\begin{array}{l}0.308^{* * *} \\
(0.084)\end{array}$ & $\begin{array}{l}0.433^{* * *} \\
(0.101)\end{array}$ & $\begin{array}{l}-0.203 \\
(0.219)\end{array}$ & $\begin{array}{l}2.504^{* * *} \\
(0.376)\end{array}$ & $\begin{array}{l}1.320^{* *} \\
(0.587)\end{array}$ & $\begin{array}{l}1.129 \\
(0.900)\end{array}$ \\
\hline Ifertil & $\begin{array}{l}0.060^{* * *} \\
(0.009)\end{array}$ & $\begin{array}{l}0.050^{* * *} \\
(0.016)\end{array}$ & $\begin{array}{l}0.075^{* * *} \\
(0.011)\end{array}$ & $\begin{array}{l}0.065^{* * *} \\
(0.009)\end{array}$ & $\begin{array}{l}0.050^{* * *} \\
(0.016)\end{array}$ & $\begin{array}{l}0.074^{* * *} \\
(0.011)\end{array}$ & $\begin{array}{l}0.048^{* * * *} \\
(0.015)\end{array}$ & $\begin{array}{l}0.024 \\
(0.021)\end{array}$ & $\begin{array}{l}0.065^{* * *} \\
(0.023)\end{array}$ \\
\hline lagr_area & $\begin{array}{l}0.110 \\
(0.079)\end{array}$ & $\begin{array}{l}0.156 \\
(0.145)\end{array}$ & $\begin{array}{l}0.029 \\
(0.096)\end{array}$ & $\begin{array}{l}0.099 \\
(0.078)\end{array}$ & $\begin{array}{l}0.188 \\
(0.149)\end{array}$ & $\begin{array}{l}0.019 \\
(0.099)\end{array}$ & $\begin{array}{l}0.076 \\
(0.150)\end{array}$ & $\begin{array}{l}0.049 \\
(0.210)\end{array}$ & $\begin{array}{l}0.086 \\
(0.374)\end{array}$ \\
\hline lpop & $\begin{array}{l}0.777^{* * *} \\
(0.056)\end{array}$ & $\begin{array}{l}1.680^{* * *} \\
(0.176)\end{array}$ & $\begin{array}{l}0.759^{* * *} \\
(0.076)\end{array}$ & $\begin{array}{l}0.772^{* * *} \\
(0.056)\end{array}$ & $\begin{array}{l}1.691^{* * *} \\
(0.176)\end{array}$ & $\begin{array}{l}0.755^{* * *} \\
(0.076)\end{array}$ & $\begin{array}{l}0.493^{* * *} \\
(0.094)\end{array}$ & $\begin{array}{l}0.629 \\
(0.583)\end{array}$ & $\begin{array}{l}0.764^{* * *} \\
(0.139)\end{array}$ \\
\hline ltract & $\begin{array}{l}-0.023^{*} \\
(0.012)\end{array}$ & $\begin{array}{l}-0.168^{* * *} \\
(0.024)\end{array}$ & $\begin{array}{r}-0.006 \\
(0.014)\end{array}$ & $\begin{array}{l}0.136^{* * *} \\
(0.037)\end{array}$ & $\begin{array}{l}-0.462 \\
(0.303)\end{array}$ & $\begin{array}{c}-0.030 \\
(0.054)\end{array}$ & $\begin{array}{l}0.097^{* *} \\
(0.042)\end{array}$ & $\begin{array}{l}-0.142^{*} \\
(0.076)\end{array}$ & $\begin{array}{l}0.035 \\
(0.076)\end{array}$ \\
\hline ltract $\hat{2}$ & & & & $\begin{array}{l}-0.009^{* * *} \\
(0.002)\end{array}$ & $\begin{array}{l}0.012 \\
(0.012)\end{array}$ & $\begin{array}{l}0.001 \\
(0.003)\end{array}$ & & & \\
\hline lappl & & & & & & & $\begin{array}{l}-0.014 \\
(0.011)\end{array}$ & $\begin{array}{l}-0.017 \\
(0.015)\end{array}$ & $\begin{array}{l}0.008 \\
(0.016)\end{array}$ \\
\hline Constant & $\begin{array}{l}7.404^{* * *} \\
(0.865)\end{array}$ & $\begin{array}{l}-5.569^{* *} \\
(2.743)\end{array}$ & $\begin{array}{l}7.845^{* * *} \\
(1.373)\end{array}$ & $\begin{array}{l}6.834^{* * *} \\
(0.868)\end{array}$ & $\begin{array}{l}-4.209 \\
(3.077)\end{array}$ & $\begin{array}{l}8.103^{* * *} \\
(1.483)\end{array}$ & $\begin{array}{l}11.031^{* * *} \\
(2.042)\end{array}$ & $\begin{array}{l}12.158 \\
(8.473)\end{array}$ & $\begin{array}{l}6.994 \\
(4.405)\end{array}$ \\
\hline Observations & 1294 & 621 & 673 & 1294 & 621 & 673 & 240 & 137 & 103 \\
\hline Number of countries & 51 & 25 & 26 & 51 & 25 & 26 & 28 & 14 & 14 \\
\hline$R^{2}$ & 0.661 & 0.429 & 0.784 & 0.667 & 0.430 & 0.784 & 0.702 & 0.645 & 0.832 \\
\hline Adjusted $R^{2}$ & 0.646 & 0.399 & 0.774 & 0.651 & 0.399 & 0.773 & 0.651 & 0.58 & 0.788 \\
\hline
\end{tabular}

Note: dependent variable is the log of agriculture, value added (constant 2005 US\$). Standard errors in parentheses.

* Significance level, $p<0.1$

*** Significance level, $p<0.05$.

*** Significance level, $p<0.01$.

(See Table A3 in Appendix). ${ }^{26}$ Schooling (schoo) measures the average years of schooling for population of 15 years old and over, as estimated by Barro and Lee (2010). We use this variable as a proxy of the stock of human capital in each country. Given the recent shift of agriculture and plant breeding towards a more science-based sector, human capital is expected to have a positive effect on agricultural value added. The other control variables were collected from FAOSTAT (faostat.fao.org). We consider the log of tractors (ltract) as an indicator of the stock of capital relevant for the sector. We include two additional variables that are likely to improve the conditions in which agricultural production takes place. The first one is total land area equipped with systems of irrigation of various types (irrig). Note that this is an indicator of the stock of equipment for irrigation and not of the effective use of it. Instead, the second variable is total consumption of fertilizers (lfertil), in log. We also include the log of agricultural area available (larea), which is the sum of areas under arable land, permanent crops, and permanent meadows and pastures, expressed in 1000 ha. Finally, we consider the $\log$ of population (lpop). In some specifications, we include as additional control, the quantity of IPRs applications (including PBRs and plant patents in the US) filed in a given year (lappl), which may be regarded as an indicator of the intensity of inventive activities in this field. The source of this variable is UPOV, which gathers the data supplied by national authorities (UPOV, 1982, 2000, 2003, 2006, 2011, 2012). We should mention that, unfortunately, this information is not complete and, when comparing the UPOV data with the reports of national offices there is frequently evidence of underreporting in the data supplied by several countries.

26 See, for instance, the classical study of Hayami and Ruttan (1970); Yamada and Ruttan (1980); and the recent empirical study of Payumo et al. (2012), in which IP protection is also considered.
Other possible control variables that may influence agricultural production, such as livestock, agricultural R\&D, innovation, agricultural machinery, and rural labour, were not included because of the lack of data, in particular, for developing countries. Therefore, we estimated the following model:

$Y_{i t}=\alpha_{i}+\beta_{x}$ lagged_ind ${ }_{i t}+\varphi_{x} X_{i t}+\mu_{i t}$,

where $Y_{i t}$ is the dependent variable, the log of agriculture value added in constant US dollars of 2005, lagged_ind $d_{i t}$ is the one year lagged index of IP protection for plant varieties, and $X_{i t}$ is the set of control variables.

Taking advantage of the panel structure of the data, we estimate the model using fixed effects and random effects methods. Once again, the Hausman test rejected the null hypothesis that individual effects are random. Table 11 displays the estimation results using fixed effects.

We have estimated all the specifications for the full sample and also restricting the sample according to development level. In the first specifications (models 1-3), most of the control variables turned out significant and with the expected signs, except for tractors, which resulted negative for the full sample and developed countries. This may be not only due to problems with data but also because there may be some decreasing returns in the use of tractors, resulting in a non-linear relation. A better indicator of agricultural machinery would be to consider the horsepower of tractors, as Hayami and Ruttan (1970) did. Unfortunately, this variable is not available for the countries of our panel. To address the issue of decreasing returns, we have tried including the square of tractors in models 4-6 to find evidence of non-linearity in their effect. For the full sample, the variable tractors turned out positive and significant while the square of tractors is negative and significant, which may confirm the existence of a non-linear effect. For the other two samples, both tractors and the square of tractors turned out not to be significant. 
Table 12

Agricultural value added and two measures of IPRs. Fixed effects estimation results.

\begin{tabular}{|c|c|c|c|c|c|c|}
\hline Model & (1) & (2) & (3) & (4) & (5) & $(6)$ \\
\hline Sample & FS & DC & LDC & FS & DC & LDC \\
\hline \multirow[t]{2}{*}{ lagged_ind } & $0.031^{* * *}$ & $0.024^{* *}$ & -0.014 & $0.027^{* * *}$ & $0.021^{*}$ & -0.015 \\
\hline & $(0.008)$ & $(0.011)$ & $(0.012)$ & $(0.008)$ & $(0.011)$ & $(0.012)$ \\
\hline \multirow[t]{2}{*}{ lagged_pat_ind } & 0.014 & $0.080^{* * *}$ & 0.004 & $0.022^{* *}$ & $0.084^{* * * *}$ & 0.005 \\
\hline & $(0.011)$ & (0.019) & $(0.012)$ & $(0.011)$ & $(0.019)$ & $(0.013)$ \\
\hline \multirow[t]{2}{*}{ schoo } & $0.045^{* * *}$ & $0.045^{* * *}$ & $0.029^{* * *}$ & $0.047^{* * * *}$ & $0.049^{* * * *}$ & $0.029^{*}$ \\
\hline & $(0.009)$ & $(0.012)$ & $(0.015)$ & $(0.009)$ & $(0.012)$ & $(0.015)$ \\
\hline \multirow[t]{2}{*}{ irrig } & $0.321^{* * *}$ & 0.147 & 0.130 & $0.245^{* * *}$ & $0.234^{* *}$ & 0.143 \\
\hline & $(0.083)$ & $(0.094)$ & $(0.220)$ & $(0.084)$ & $(0.099)$ & $(0.224)$ \\
\hline \multirow[t]{2}{*}{ lfertil } & $0.052^{* * *}$ & 0.013 & $0.093^{* * *}$ & $0.059^{* * *}$ & 0.011 & $0.094^{* * * *}$ \\
\hline & $(0.011)$ & $(0.021)$ & $(0.013)$ & $(0.011)$ & $(0.021)$ & $(0.013)$ \\
\hline \multirow[t]{2}{*}{ lagr_area } & $0.140^{*}$ & $0.476^{* * *}$ & -0.128 & 0.122 & $0.595^{* * *}$ & -0.122 \\
\hline & $(0.082)$ & $(0.155)$ & $(0.096)$ & $(0.082)$ & (0.159) & $(0.097)$ \\
\hline \multirow[t]{2}{*}{ lpop } & $0.795^{* * *}$ & $0.998^{* * * *}$ & $0.889^{* * * *}$ & $0.778^{* * *}$ & $1.011^{* * *}$ & $0.891^{* * * *}$ \\
\hline & $(0.059)$ & $(0.190)$ & $(0.079)$ & $(0.059)$ & $(0.189)$ & $(0.079)$ \\
\hline \multirow[t]{2}{*}{ ltract } & $-0.035^{* * *}$ & $-0.192^{* * *}$ & 0.020 & $0.158^{* * *}$ & $-1.071^{* * *}$ & 0.037 \\
\hline & $(0.013)$ & $(0.025)$ & $(0.015)$ & $(0.044)$ & $(0.308)$ & $(0.058)$ \\
\hline \multirow[t]{2}{*}{ ltract $\hat{2}$} & & & & $-0.010^{* * *}$ & $0.034^{* * * *}$ & -0.001 \\
\hline & & & & $(0.002)$ & $(0.012)$ & $(0.003)$ \\
\hline \multirow[t]{2}{*}{ Constant } & $7.108^{* * *}$ & 3.477 & $6.891^{* * *}$ & $6.558^{* * *}$ & $7.706^{* *}$ & $6.728^{* * * *}$ \\
\hline & $(0.909)$ & $(3.001)$ & $(1.393)$ & $(0.909)$ & $(3.327)$ & (1.489) \\
\hline Observations & 1,167 & 551 & 616 & 1,167 & 551 & 616 \\
\hline Number of countries & 46 & 22 & 24 & 46 & 22 & 24 \\
\hline$R^{2}$ & 0.679 & 0.474 & 0.805 & 0.685 & 0.482 & 0.805 \\
\hline Adjusted $R^{2}$ & 0.664 & 0.445 & 0.795 & 0.67 & 0.453 & 0.794 \\
\hline
\end{tabular}

Note: dependent variable is the log of agriculture, value added (constant 2005 US\$). Standard errors in parentheses.

* Significance level, $p<0.1$

*** Significance level, $p<0.05$.

*** Significance level, $p<0.01$.

We have also estimated another specification in which we include the quantity of IPRs applications for plant variety (models $7-9) .{ }^{27}$ It must be noted that in this case, the number of countries in the regressions drops significantly because of the lack of data. We find that the number of applications is not significant in all of the samples. This result is probably explained by the fact that this variable is indeed a very rough proxy of innovation output especially in a sample comprising many developing countries.

Our main point of interest is the effect of the index of IP protection. It appears positive and significant for the full sample and for developed countries in all specifications, except when including IPRs applications in which case the number of observations drops substantially, thereby making the regressions less reliable. In contrast, the index is not significant for developing countries in all of the specifications. of Table 11 but also including the patent index of Ginarte and Park (1997) among the covariates (lagged_pat_ind). Both indices measure different aspects of IP protection systems because they are constructed to characterize IPRs for different types of innovations. For instance, machinery, fertilizers and more sophisticated prodpatent systems, whose strength is possibly captured by the Ginarte and Park (1997) index. Instead, our index is expected to reflect the effect of IPRs on biological innovations such as plant varieties, genes and processes that are used in biotechnology. Therefore, we believe that by capturing different dimensions of IP protection in agriculture, both indices may affect agricultural production and may have complementary effects.
Finally, in Table 12, we report a set of regressions similar to those ucts used in "precision agriculture" are typically protected using

In general terms, it is worth stressing two main differences between our index and the patent index. First, our index is available yearly whereas the patent index is available only at discrete 5-year intervals $(1960,1965, \ldots, 2005)$. The second difference is the sample of countries covered. The patent index comprises 110 countries, while our index covers 69 countries, and the overlap is 56 countries. For these reasons, the regression exercises reported in Table 12 cover the more restricted sample of countries for which we have both indices and use the same value for the patent index every five years. ${ }^{28}$ The two IPRs indices in the regressions of Table 12 are included with a one-year lag.

We find that the new estimated coefficients for our index are very similar to the ones estimated previously in terms of sings and significance. The patent index is also significant and positive for the samples of developed countries and for the full sample in the fourth model. However, it is not significant for the full sample in model 1 and for the samples of developing countries. The adjusted $R^{2}$ increases in the models with both indices, indicating that they may both be relevant in explaining agricultural production and that there may be some complementarity between them.

In our interpretation, the two indices measure some shared dimensions of a general attitude towards IP protection in each country. However, given that both indices are significant in some specifications, they also probably capture different aspects of IP protection, both of which affect agricultural production.

The main conclusion of this section is that our index performs reasonably well in this empirical application. The estimated effect of the index does not change in the different specifications, which suggests that we have probably identified a rather robust correlation. The index has a significant effect in agricultural productions for the full sample of countries. Interestingly, the evidence we found

\footnotetext{
27 We have also estimated the model using registered titles but we consider that applications may be a better indicator to capture innovation effort. The coefficients for registered IPRs resulted non statistical significant for all the samples, and the effect of the index of IP protection remained unchanged.
}

${ }^{28}$ For example, we have used the value of the index in 1970 for all the years between 1971 and 1974 . 
Table A1

Evolution of the Index of Intellectual Property Protection for plant varieties.

\begin{tabular}{|c|c|c|c|c|c|c|c|c|c|c|}
\hline Country & 1965 & 1970 & 1975 & 1980 & 1985 & 1990 & 1995 & 2000 & 2005 & 2010 \\
\hline Albania & 0 & 0 & 0 & 0 & 0 & 0 & 0.80 & 0.80 & 3.51 & 3.51 \\
\hline Argentina & 0.20 & 0.20 & 0.77 & 0.77 & 0.77 & 0.77 & 1.84 & 2.04 & 2.04 & 2.04 \\
\hline Australia & 0 & 0 & 0 & 0 & 0 & 2.18 & 3.38 & 3.71 & 3.71 & 3.71 \\
\hline Austria & 0.20 & 0.20 & 0.20 & 0.20 & 0.40 & 0.60 & 2.12 & 2.32 & 3.66 & 3.66 \\
\hline Azerbaijan & & & & & & & 0 & 0.80 & 4.51 & 4.51 \\
\hline Belarus & & & & & & & 0.71 & 0.71 & 4.51 & 4.51 \\
\hline Belgium & 0.40 & 0.40 & 1.11 & 1.45 & 1.65 & 1.85 & 1.85 & 1.85 & 1.85 & 1.85 \\
\hline Bolivia & 0 & 0 & 0 & 0 & 0 & 0 & 0.20 & 2.98 & 2.98 & 2.98 \\
\hline Brazil & 0 & 0 & 0 & 0 & 0 & 0 & 0.00 & 2.78 & 2.78 & 2.78 \\
\hline Bulgaria & 0 & 0.20 & 0.20 & 0.20 & 0.20 & 0.20 & 0.60 & 3.66 & 3.66 & 3.66 \\
\hline Canada & 0.20 & 0.20 & 0.20 & 0.20 & 0.60 & 0.80 & 1.98 & 1.98 & 1.98 & 1.98 \\
\hline Chile & 0 & 0 & 0 & 0 & 0 & 0.20 & 0.91 & 1.98 & 1.98 & 1.98 \\
\hline China & & & & & 0.20 & 0.20 & 0.20 & 1.84 & 2.04 & 2.04 \\
\hline Colombia & 0 & 0 & 0 & 0 & 0 & 0 & 1.77 & 2.84 & 3.04 & 3.04 \\
\hline Costa Rica & 0 & 0 & 0 & 0 & 0 & 0 & 0 & 0.40 & 0.40 & 4.11 \\
\hline Croatia & & & & & & & 0 & 2.91 & 4.51 & 4.66 \\
\hline Czech Republic & & & & & & 0.71 & 1.98 & 3.12 & 3.46 & 3.46 \\
\hline Denmark & 0 & 0 & 0.33 & 0.33 & 1.07 & 1.98 & 1.98 & 4.66 & 4.66 & 4.66 \\
\hline Dominican Republic & 0.40 & 0.40 & 0.40 & 0.40 & 0.40 & 0.40 & 0.40 & 0.40 & 0.60 & 3.31 \\
\hline Ecuador & 0 & 0 & 0 & 0 & 0 & 0 & 0.20 & 2.98 & 2.98 & 2.98 \\
\hline Estonia & & & & & & & 0.80 & 3.66 & 3.66 & 3.66 \\
\hline Finland & 0 & 0 & 0 & 0 & 0.20 & 0.20 & 3.12 & 3.32 & 3.66 & 4.66 \\
\hline France & 0.40 & 1.11 & 1.45 & 1.45 & 1.98 & 1.98 & 1.98 & 2.18 & 2.18 & 2.18 \\
\hline Georgia & & & & & & & 0.60 & 2.60 & 2.60 & 3.46 \\
\hline Germany & 0.60 & 1.85 & 1.85 & 1.85 & 2.99 & 3.32 & 3.32 & 4.66 & 4.66 & 4.66 \\
\hline Hungary & 0 & 0.20 & 0.20 & 0.20 & 0.87 & 0.87 & 1.98 & 1.98 & 2.31 & 3.66 \\
\hline Iceland & 0 & 0 & 0 & 0 & 0 & 0 & 0.20 & 0.80 & 2.66 & 3.66 \\
\hline Ireland & 0.20 & 0.40 & 0.40 & 0.40 & 1.78 & 1.98 & 1.98 & 3.32 & 3.32 & 3.32 \\
\hline Israel & 0.40 & 0.40 & 2.11 & 2.45 & 2.78 & 2.78 & 2.78 & 4.31 & 4.31 & 4.31 \\
\hline Italy & 0.40 & 0.40 & 1.26 & 1.79 & 1.99 & 1.99 & 1.99 & 2.99 & 2.99 & 2.99 \\
\hline Japan & 0.71 & 0.71 & 1.11 & 1.31 & 1.98 & 1.98 & 2.98 & 3.31 & 3.66 & 3.66 \\
\hline Jordan & 0 & 0 & 0 & 0 & 0 & 0 & 0 & 2.31 & 4.31 & 4.31 \\
\hline Kenya & 0.40 & 0.40 & 1.11 & 1.11 & 1.11 & 1.11 & 1.11 & 1.98 & 1.98 & 1.98 \\
\hline Kyrgyzstan & & & & & & & 0 & 3.80 & 3.80 & 3.80 \\
\hline Latvia & & & & & & & 0.80 & 0.80 & 3.66 & 3.66 \\
\hline Lithuania & & & & & & 0.40 & 0.40 & 0.80 & 3.66 & 3.66 \\
\hline Mexico & 0 & 0 & 0 & 0 & 0 & 0 & 0.80 & 1.98 & 1.98 & 1.98 \\
\hline Morocco & 0.20 & 0.20 & 0.20 & 0.20 & 0.20 & 0.20 & 0.20 & 2.11 & 2.31 & 3.31 \\
\hline Netherlands & 0.71 & 1.45 & 1.45 & 1.45 & 1.78 & 1.98 & 1.98 & 3.51 & 3.66 & 3.66 \\
\hline New Zealand & 0.40 & 0.40 & 0.40 & 0.40 & 1.72 & 1.72 & 2.12 & 2.12 & 2.12 & 2.12 \\
\hline Nicaragua & 0 & 0 & 0 & 0 & 0 & 0 & 0 & 1.57 & 2.24 & 2.24 \\
\hline Norway & 0 & 0 & 0 & 0 & 0 & 0 & 1.78 & 1.78 & 1.78 & 1.98 \\
\hline Oman & 0 & 0 & 0 & 0 & 0 & 0 & 0 & 0.60 & 0.60 & 3.31 \\
\hline Panama & 0 & 0 & 0 & 0 & 0 & 0 & 0 & 2.18 & 2.18 & 2.18 \\
\hline Paraguay & 0.20 & 0.20 & 0.20 & 0.20 & 0.20 & 0.20 & 0.77 & 1.44 & 1.84 & 1.84 \\
\hline Peru & 0 & 0 & 0 & 0 & 0 & 0 & 2.11 & 2.51 & 2.51 & 2.51 \\
\hline Poland & & & & & & 0.67 & 1.07 & 3.12 & 3.66 & 3.66 \\
\hline Portugal & 0 & 0 & 0 & 0 & 0 & 0.57 & 1.64 & 1.84 & 2.04 & 2.04 \\
\hline Republic of Korea & 0.20 & 0.20 & 0.40 & 0.40 & 0.40 & 1.00 & 1.00 & 2.71 & 3.71 & 3.71 \\
\hline Republic of Moldova & & & & & & & 0.80 & 3.51 & 3.51 & 3.66 \\
\hline Romania & 0 & 0.20 & 0.20 & 0.20 & 0.20 & 0.20 & 0.60 & 3.46 & 4.66 & 4.66 \\
\hline Russian Federation & & & & & & & 2.80 & 3.80 & 3.80 & 3.80 \\
\hline Singapore & 0.40 & 0.40 & 0.40 & 0.40 & 0.40 & 0.40 & 0.80 & 0.80 & 3.51 & 3.51 \\
\hline Slovakia & & & & & & & 2.12 & 3.12 & 3.12 & 4.46 \\
\hline Slovenia & & & & & & & 0.80 & 3.51 & 3.51 & 3.51 \\
\hline South Africa & 0.40 & 0.40 & 0.40 & 1.45 & 1.78 & 1.98 & 1.98 & 3.18 & 3.18 & 3.18 \\
\hline Spain & 0.20 & 0.20 & 0.71 & 1.05 & 1.05 & 1.30 & 1.50 & 2.70 & 2.70 & 3.37 \\
\hline Sweden & 0 & 0.40 & 1.30 & 1.30 & 1.64 & 1.84 & 1.84 & 2.37 & 2.37 & 3.66 \\
\hline Switzerland & 0 & 0.40 & 0.40 & 1.65 & 1.98 & 2.18 & 2.18 & 2.18 & 2.18 & 3.51 \\
\hline T.F.Y.R. of Macedonia & & & & & & & 0.80 & 0.80 & 0.80 & 2.31 \\
\hline Trinidad and Tobago & 0.40 & 0.40 & 0.40 & 0.40 & 0.40 & 0.40 & 0.40 & 1.78 & 1.78 & 1.78 \\
\hline Tunisia & 0 & 0 & 0 & 0 & 0 & 0 & 1.71 & 1.71 & 2.71 & 2.71 \\
\hline Turkey & 0 & 0.20 & 0.20 & 0.20 & 0.20 & 0.20 & 0.40 & 0.60 & 2.46 & 3.46 \\
\hline Ukraine & & & & & & & 3.47 & 3.47 & 3.47 & 3.66 \\
\hline United Kingdom & 1.31 & 1.65 & 1.65 & 1.65 & 2.32 & 2.32 & 2.32 & 3.66 & 3.66 & 3.66 \\
\hline United States of America & 0.80 & 1.37 & 1.37 & 1.37 & 2.24 & 2.24 & 3.57 & 3.71 & 3.71 & 3.71 \\
\hline Uruguay & 0.20 & 0.20 & 0.20 & 0.20 & 0.20 & 0.20 & 0.87 & 2.04 & 2.04 & 2.18 \\
\hline Uzbekistan & & & & & & & 0 & 0.80 & 3.51 & 3.51 \\
\hline Viet Nam & 0 & 0 & 0 & 0 & 0 & 0.40 & 0.40 & 0.40 & 2.11 & 3.11 \\
\hline
\end{tabular}

Note: Data for the rest of the years between 1961 and 2011 are available upon request. 
is consistent with the notion that IPRs do not affect developed and developing countries in the same way.

\section{Concluding remarks}

The main contribution of this paper is the construction of a new index of intellectual property protection for plant varieties for a set of developed and developing countries. This index provides a synthetic score that summarizes the salient features of IPRs systems for the protection of plant varieties. Our contention is that the index is able to capture important features of the variation in IP protection in the agricultural sector across countries. Accordingly, we believe that the index can be employed as a useful tool for future research on innovation, productivity, trade, growth and technology transfer in the agricultural sector, providing a useful contribution to comparative studies of innovation policies in the agricultural sector in both developed and developing countries. In addition, the index intends to complement other measures of the strength of IP protection that are applicable to other sectors of the economy.

The index shows that IP protection has been increasing over the years and developing countries have been adopting tighter systems since the mid-1990s. The historical evolution of the index is in line with evidence found for other types of IPRs. There has been a progressive adoption of tighter IPRs regimes worldwide, especially since the signing of the TRIPS agreement, which also demanded higher IP protection for plant breeding activities.

We have established significant correlations between the index and variables such as GDP per capita, the rate of urbanization, openness to trade, institutional factors, and the relevance of agriculture for the economy. However, the influence of some of these variables is non-linear, as demonstrated when examining the countries according to their development level. Furthermore, we find a positive and significant correlation between the strengthening of IP protection and agricultural valued added for developed countries, but we are not able to establish any significant correlation for developing countries.

To conclude, the evidence presented in this paper supports the hypothesis that the effect of IPRs may be different across sectors, technologies and development levels. For this reason, a more cautious approach towards the adoption of a global and harmonized IP protection system (such as that emerging from TRIPS) should be in order. In this sense, our results are in line with the historical appraisal of Khan and Sokoloff (2009, p. 241), who argue that “... intellectual property rights best promoted the progress of science and arts when they evolved in tandem with other institutions and in accordance with the needs and interests of social and economic development in each nation".

\section{Acknowledgements}

The authors would like to thank Walter Park for kindly making part of his dataset available. We are also thankful to Giovanni Dosi, Marco Dueñas, Giovanni Federico, Jim Bessen, Luigi Orsenigo and four anonymous referees for useful comments and suggestions. An earlier version of this paper was presented at the DRUID Academy Conference 2013 for doctoral students in Economics and Management of Innovation, Technology and Organizations, Aalborg, Denmark, 16th-18th January 2013.

\section{Appendix.}

See Tables A1-A3.
Table A2

Classification of countries according to development and income level.

Developed countries
Australia, Austria, Belgium, Bulgaria, Canada, Czech Republic, Denmark,
Estonia, Finland, France, Germany, Hungary, Iceland, Ireland, Italy, Japan,
Latvia, Lithuania, Netherlands, New Zealand, Norway, Poland, Portugal,
Romania, Slovakia, Slovenia, Spain, Sweden, Switzerland, United
Kingdom, United States of America
Developing countries
Albania, Argentina, Azerbaijan, Belarus, Bolivia (Plurinational State of),
Brazil, Chile, China, Colombia, Costa Rica, Croatia, Dominican Republic,
Ecuador, Georgia, Israel, Jordan, Kenya, Kyrgyzstan, Mexico, Morocco,
Nicaragua, Oman, Panama, Paraguay, Peru, Republic of Korea, Republic
of Moldova, Russian Federation, Singapore, South Africa, The former
Yugoslav Republic of Macedonia, Trinidad and Tobago, Tunisia, Turkey,
Ukraine, Uruguay, Uzbekistan, Viet Nam
High-income countries
Australia, Austria, Belgium, Canada, Croatia, Czech Republic, Denmark,
Estonia, Finland, France, Germany, Hungary, Iceland, Ireland, Israel, Italy,
Japan, Netherlands, New Zealand, Norway, Oman, Poland, Portugal,
Republic of Korea, Singapore, Slovakia, Slovenia, Spain, Sweden,
Switzerland, Trinidad and Tobago, United Kingdom, United States of
America
Middle-income countries
Argentina, Azerbaijan, Belarus, Brazil, Bulgaria, Chile, China, Colombia,
Costa Rica, Dominican Republic, Ecuador, Jordan, Latvia, Lithuania,
Mexico, Panama, Peru, Romania, Russian Federation, South Africa, The
former Yugoslav Republic of Macedonia, Tunisia, Turkey, Uruguay
Morocco, Nicaragua, Paraguay, Republic of Moldova, Ukraine,
Uzbekistan, Viet Nam
Mountries

Table A3

Variables used in the econometric exercises.

\begin{tabular}{|c|c|c|c|}
\hline Variable & Source & Mean & Std. dev \\
\hline $\begin{array}{l}\text { GDP per capita (1990 } \\
\text { International } \\
\text { Geary-Khamis dollars) } \\
\text { (log) }\end{array}$ & Maddison Project & 8.76 & 0.83 \\
\hline $\begin{array}{l}\text { Urban population } \\
\text { (1000)/Rural population } \\
(1000)\end{array}$ & FAOSTAT & 2.57 & 3.09 \\
\hline Polity2 & Marshall et al. (2010) & 4.24 & 7.2 \\
\hline Economic freedom & The Heritage Foundation & 6.47 & 1.27 \\
\hline $\begin{array}{l}\text { Agricultural export value } \\
\text { index }(2004-2006=100) \\
(\%)(\log )\end{array}$ & FAOSTAT & 3.51 & 1.15 \\
\hline $\begin{array}{l}\text { Openness at } 2005 \text { constant } \\
\text { prices }(\%)(\log )\end{array}$ & Heston et al. (2012) & 3.87 & 0.72 \\
\hline $\begin{array}{l}\text { Dummy for TRIPS } \\
\text { agreement }\end{array}$ & WIPO & 0.39 & 0.49 \\
\hline $\begin{array}{l}\text { Educational attainment for } \\
\text { total population aged } 15 \\
\text { or over }\end{array}$ & Barro and Lee (2010) & 7.55 & 2.63 \\
\hline $\begin{array}{l}\text { Total area equipped for } \\
\text { irrigation/(agricultural } \\
\text { area/land area) }\end{array}$ & FAOSTAT & 0.85 & 0.11 \\
\hline $\begin{array}{l}\text { Agricultural area (1000 ha) } \\
\quad(\log )\end{array}$ & FAOSTAT & 8.95 & 2.04 \\
\hline $\begin{array}{l}\text { Consumption of total } \\
\text { fertilizers (log) }\end{array}$ & FAOSTAT & 2.03 & 4.88 \\
\hline $\begin{array}{l}\text { Agricultural machinery, } \\
\text { tractors (log) }\end{array}$ & FAOSTAT & 10.93 & 2.21 \\
\hline $\begin{array}{l}\text { Population in thousands } \\
\text { (log) }\end{array}$ & FAOSTAT & 16.2 & 1.48 \\
\hline $\begin{array}{l}\text { Total applications filed for } \\
\text { titles for plant varieties }\end{array}$ & WIPO and UPOV & 4.25 & 1.68 \\
\hline $\begin{array}{l}\text { Total registrations of titles } \\
\text { for plant varieties }\end{array}$ & WIPO and UPOV & 3.99 & 1.63 \\
\hline
\end{tabular}




\section{References}

Alston, J., Venner, R., 2002. The effects of the US Plant Variety Protection Act on wheat genetic improvement. Research Policy 31 (4), 527-542.

Anand, S., Sen, A., 1994. Human Development Index: Methodology and Measurement. Occasional Papers, Human Development Report Office, hdr.undp.org/en/media/AnandandSenHDI.pdf.

Barro, R., Lee, J.W., 2010. A New Data Set of Educational Attainment in the World, 1950-2010. NBER Working Paper No. 15902.

Beintema, N., Stads, G., Fuglie, K., Heisey, P., 2012. ASTI Global Assessment of Agricultural R\&D Spending: Developing Countries Accelerate Investment. International Food Policy Research Institute and Global Forum on Agricultural Research, Washington, DC/Rome, Available at: http://www.ifpri.org/PUBLICATION/ ASTI-GLOBAL-ASSESSMENT-AGRICULTURAL-RD-SPENDING?print

Blair, O., 1973. Inventions in the Soviet Union. International Lawyer 7 (2), 485-491.

Campi, M., Dueñas, M., 2014. Intellectual Property Rights and International Trade of Agricultural Products, Available at SSRN: http://ssrn.com/abstract $=2459830$

Cohen, S., Morgan, G., 2008. Monsanto Technology LLC v. Cargill: a matter of construction. Nature Biotechnology 26, 289-291.

Correa, C., 2009. Enforcing border measures: importation of GMO soybean meal from Argentina. In: Li, X., Correa, C. (Eds.), Intellectual Property Enforcement: International Perspectives. Edward Elgar Publishing, Cheltenham.

Dasgupta, P., Weale, M., 1992. On measuring the quality of life. World Development 20.1, 119-131.

Dosi, G., Marengo, L., Pasquali, C., 2006. How much should society fuel the greed of innovators? On the relations between appropriability, opportunities and the rates of innovation. Research Policy 35 (8), 1110-1121.

Dutfield, G. (2011). Food, Biological Diversity and Intellectual Property: The Role of the International Union for the Protection of New Varieties of Plants (UPOV). QUNO Intellectual Property Issues Paper 9, 1-20.

Gadbaw, R.M., Richards, T.J., 1988. Intellectual Property Rights: Global Consensus, Global Conflict? Westview Press.

Ganea, P., Garde, T., Woolley, A., Goldstein, P., Straus, J., 2009. Intellectual Property in Asia: Law, Economics, History and Politics. Springer, Berlin.

Ginarte, J., Park, W., 1997. Determinants of patent rights: a cross-national study. Research Policy 26 (3), 283-301.

Hayami, Y., Ruttan, V.W., 1970. Agricultural productivity differences among countries. American Economic Review 60 (5), 895-911.

Heitz, A., 1987. The History of Plant Variety Protection. UPOV, Geneva, pp. 53-99.

Heston, A., R. Summers and B. Aten (2012). Penn World Table Version 7.1. Center for International Comparisons of Production, Income and Prices at the University of Pennsylvania, July.

Janis, M., 2014. Patenting plants: a comparative synthesis. In: Okediji, R., Bagley, M.A. (Eds.), Patent Law in Global Perspective. Oxford University Press, Oxford.

Joint Research Centre-European Commission, 2008. Handbook on Constructing Composite Indicators: Methodology and User Guide. OECD Publishing.

Kanwar, S., Evenson, R., 2003. Does intellectual property protection spur technological change? Oxford Economic Papers 55.2, 235-264.

Khan, Z., Sokoloff, K., 2009. Historical perspectives on patent systems in economic development. In: Netanel, N.W. (Ed.), The Development Agenda. Global Intellectual Property and Developing Countries. Oxford University Press, Oxford.

Kranakis, E., 2007. Patents and power: European patent-system integration in the context of globalization. Technology and Culture 48 (4), 689-728.

Lederman, D. and L. Saenz (2005). Innovation around the World, 1960-2000. World Bank Policy Research Working Paper 3774.

Léger, A., 2005. Intellectual property rights in Mexico: do they play a role? World Development 33 (11), 1865-1879.

Lerner, J. (2002). Patent Protection and Innovation Over 150 Years. Technical Report 8977, National Bureau of Economic Research, Inc.

Liu, M. and S. La Croix (2014). A cross-country index of intellectual property rights in pharmaceutical inventions. Research Policy, http://dx.doi.org/10.1016/ j.respol.2014.07.004

Louwaars, N.P., Tripp, R., Eaton, D., Henson-Apollonio, V., Hu, R., Mendoza, M., Muhhuku, F., Pal, S., Wekundah, J., 2005. Impacts of Strengthened Intellectual Property Rights Regimes on the Plant Breeding Industry in Developing Countries. Report Commissioned by the World Bank, Wageningen, The Netherlands.

Marshall, M.G., K. Jaggers and R. Gurr (2010). Polity IV Project. Political Regime Characteristics and Transitions, 1800-2010, Center for International Development and Conflict Management, University of Maryland, College Park, available at: www.cicdcm.umd.edu/isncr/polity [downloaded on July 2012].

Moser, P., Rhode, P.W., 2011. Did plant patents create the American rose? In: Lerner, J., Stern, S. (Eds.), The Rate and Direction of Inventive Activity Revisited. The University of Chicago Press, Chicago.

Nuvolari, A., Tartari, V., 2014. Innovation, appropriability and productivity growth in agriculture: a broad historical viewpoint. In: Cimoli, M., et al. (Eds.), Intellectual Property Rights: Legal and Economic Challenges for Development. Oxford University Press, Oxford.

Olmstead, A.L., Rhode, P.W., 2008. Creating Abundance. Biological Innovation and American Agricultural Development. Cambridge University Press, Cambridge.

Park, W. (2001). Intellectual property and patent regimes. Economic Freedom of the World: 2001. Annual Report, 101-118.

Park, W., 2008. International patent protection: 1960-2005. Research Policy 37 (4), 761-766.

Park, W. and S. Wagh (2002). Index of patent rights. Economic freedom of the world: 2002, Annual Report, 33-43.

Payumo, J., Grimes, H., Wandschneider, P., 2012. Status of national intellectual property rights (IPRs) systems and its impact to agricultural development: a time series cross section data analysis of TRIPS member-countries. International Journal of Intellectual Property Management 5 (1), 82-99.

Pugatch, M.P., 2006. Measuring the strength of national pharmaceutical intellectual property regimes: creating a new pharmaceutical IP index. Journal of World Intellectual Property 9 (4), 373-391.

Rapp, R.T., Rozek, R.P., 1990. Benefits and Costs of Intellectual Property Protection in Developing Countries. National Economic Research Associates, Washington, DC.

Reynolds, T. (2004) Quantifying the evolution of copyright and trademark law. Doctoral Dissertation. Washington DC: American University.

Sala-I-Martin, X., B. Blbao-Osorio, J., Blanke, M. Hanouz and T. Geiger (2012) The Global Competitiveness Index 2011-2012: Setting the Foundations for Strong Productivity, World Economic Forum, available at: http://www3. weforum.org/docs/GCR2011-12/4.GCR2011-2012Chapter1.1GCI.pdf [downloaded on November 2012]

Sherwood, R.M., 1996. Intellectual property systems and investment stimulation: the rating of systems in eighteen developing countries. Idea 37 (2) 261-370.

Teece, D., 1986. Profiting from technological innovation: implications for integration, collaboration, licensing and public policy. Research Policy 15, 285-305.

United Nations (2012). World Economic Situation and Prospects 2012. New York United Nations.

UPOV (1961). Act of 1961. International Convention for the Protection of New Varieties of Plants. Available at: http://upov.int/upovlex/en/acts.html

UPOV (1978). Act of 1978. International Convention for the Protection of New Varieties of Plants. Available at: http://upov.int/upovlex/en/acts.html

UPOV (1991). Act of 1991. International Convention for the Protection of New Varieties of Plants. Available at: http://upov.int/upovlex/en/acts.html

UPOV (1982). Plant Varieties, International Union for the Protection of New Varieties of Plants, Geneva.

UPOV (2000). Plant variety protection statistics for the period 1995-1999 (C/34/7 International Union for the Protection of New Varieties of Plants, Geneva.

UPOV (2003). Plant variety protection statistics for the period 1998-2002 (C/37/7, International Union for the Protection of New Varieties of Plants, Geneva.

UPOV (2006). Plant variety protection statistics for the period 2001-2005 (C/40/7_Rev, International Union for the Protection of New Varieties of Plants Geneva.

UPOV (2011). Plant variety protection statistics for the period 2006-2010 (C/45/7_Rev, International Union for the Protection of New Varieties of Plants, Geneva.

UPOV (2012). Plant variety protection statistics for the period 2007-2011 (C/44/7_Rev, International Union for the Protection of New Varieties of Plants, Geneva.

WIPO (2009). Exclusions from Patentability and Exceptions and Limitations to Patentees' Rights. Electronic Document. Available at: www.wipo.int/ meetings/en/doc_details.jsp?doc_id = 116712

Yamada, S., Ruttan, V.W., 1980. International comparisons of productivity in agriculture. In: Kendrick, J., Vaccara, B. (Eds.), New Developments in Productivity Measurement. The University of Chicago Press, Chicago, pp. 507-594. 